\title{
Association between obesity and asthma in 4-11 year old children in the UK
}

\author{
J I Figueroa-Muñoz, S Chinn, R J Rona
}

\begin{abstract}
Background-There is evidence of a positive association between asthma and obesity in adults and in children. We investigated, in a large sample of English and Scottish primary school children, whether there is a consistent association between fatness and asthma symptoms in Britain.
\end{abstract}

Methods-A cross sectional analysis was made of 18218 children aged 4-11 years who participated in the 1993 or 1994 surveys of the National Study of Health and Growth (NSHG). Children belonged either to English or Scottish representative samples, or an English inner city sample. Asthma attacks in the previous year, occasional wheeze, or persistent wheeze were the symptoms used in the analysis. Body mass index (BMI) and the sum of triceps and subscapular skinfolds converted to standard deviation scores (SDS) were used to assess levels of fatness. Results-A total of 14908 children (81.8\%) were included in the analysis. In the multiple logistic analysis BMI and asthma (asthma attacks or wheeze) were associated in the representative sample (OR for the comparison of the 10th and 90th centiles of BMI 1.28, 95\% CI 1.11 to 1.48 ), but sum of skinfolds was unrelated to asthma symptoms in most analyses. The association between asthma and BMI was stronger in girls than in boys in the inner city sample, but less convincingly in the representative sample.

Conclusions-Levels of obesity are associated with asthma symptoms regardless of ethnicity. The association is more consistent for BMI than for sum of skinfolds, partly because obese children are more advanced in their maturation than other children. There is some evidence that, as in adults, the association is stronger in girls than in boys, but only in the multiethnic inner city sample.

(Thorax 2001;56:133-137)

Keywords: asthma; obesity; body mass index; ethnicity

Figueroa-Muñoz

S Chinn

R J Rona

Correspondence to: Dr J I Figueroa-Muñoz jose.figueroa-munoz@kcl.ac.uk

Received 19 June 2000 Returned to authors 9 August 2000

Revised version received

25 September 2000

Accepted for publication

21 October 2000
In the last 20 years there has been a rise in the prevalence of asthma in children ${ }^{1}$ and adults ${ }^{2}$ and an increase also in the prevalence of obesity in adults and children..$^{3-5}$ A positive association between asthma and obesity has been reported in adults, ${ }^{6-8}$ with such an association being more evident in women ${ }^{910}$ and in adolescent girls than boys. ${ }^{11} \mathrm{~A}$ similar association between asthma symptoms and obesity has been reported in children. ${ }^{12-16}$ One of the reports also indicated that asthma severity was associated with overweight. ${ }^{16}$ However, there has been also a suggestion that asthma may be more frequent in underweight subjects. ${ }^{17}$

Previous reports of the association of asthma/asthma symptoms and obesity in childhood are mainly based on small studies, studies that were carried out long ago, or on those in which the methodology for standardising subcutaneous skinfold thickness and body mass index (BMI) was unsound. The National Study of Health and Growth (NSHG) collected information on respiratory symptoms and anthropometric measurements in 4-11 year old English and Scottish children until $1994^{3418}$ and included a large sample of primary school children from the major ethnic groups in Britain. The study provides an opportunity for assessing the consistency of the association between asthma and obesity in white, black, and South Asian children, and also for assessing whether the association is restricted only to girls. This is particularly important for discussing possible mechanisms for the relation between asthma and obesity in adults and children.

\section{Methods}

The NSHG collected data from 4-11 year old primary school children in England and Scotland from 1972 to 1994 . Information was

Table 1 Demographic characteristics of the 14908 children included in the analyses stratified by sample

\begin{tabular}{|c|c|c|}
\hline & $\begin{array}{l}\text { White } \\
\text { representative } \\
(n=9507)\end{array}$ & $\begin{array}{l}\text { Inner city } \\
\text { England } \\
(n=5401)\end{array}$ \\
\hline \multicolumn{3}{|l|}{ Sex } \\
\hline Boys & $4845(51.0 \%)$ & $2698(50.0 \%)$ \\
\hline Girls & $4662(49.0 \%)$ & $2703(50.0 \%)$ \\
\hline \multicolumn{3}{|l|}{$\begin{array}{l}\text { No of children per } \\
\text { household }\end{array}$} \\
\hline 1 & $840(8.8 \%)$ & $460(8.5 \%)$ \\
\hline 2 & $4182(44.0 \%)$ & $1290(23.9 \%)$ \\
\hline 3 & $2495(26.2 \%)$ & $1122(20.8 \%)$ \\
\hline 4 & $956(10.0 \%)$ & $841(15.6 \%)$ \\
\hline$\geqslant 5$ & $637(4.2 \%)$ & $1159(21.4 \%)$ \\
\hline NK & $397(4.2 \%)$ & $529(9.8 \%)$ \\
\hline \multicolumn{3}{|l|}{ Social class } \\
\hline Non-manual & $2819(29.7 \%)$ & $664(12.3 \%)$ \\
\hline Skilled manual & $2921(30.6 \%)$ & $1099(20.4 \%)$ \\
\hline Semi \& unskilled & $1323(13.9 \%)$ & $872(16.1 \%)$ \\
\hline $\begin{array}{l}\text { One parent family } \\
\text { (mother) }\end{array}$ & $1792(18.9 \%)$ & $1630(30.2 \%)$ \\
\hline NK & $661(6.9 \%)$ & $1136(21.0 \%)$ \\
\hline \multicolumn{3}{|l|}{ Ethnicity } \\
\hline White & $9507(100.0 \%)$ & $1784(33.0 \%)$ \\
\hline Afro-Caribbean & - & $881(16.3 \%)$ \\
\hline Urdu & - & $366(6.8 \%)$ \\
\hline Gujarati & - & $335(6.2 \%)$ \\
\hline Punjabi & - & $978(18.0 \%)$ \\
\hline Other Asian & - & $437(8.1 \%)$ \\
\hline Other & - & $558(10.3 \%)$ \\
\hline Unknown & - & $62(1.1 \%)$ \\
\hline
\end{tabular}

$\mathrm{NK}=$ not known. 
Table 2 Biological characteristics of the 14908 children in the England and Scotland white representative sample and the English inner city sample included in the analysis

\begin{tabular}{llllll}
\hline & \multicolumn{2}{l}{ White representative } & & \multicolumn{2}{l}{ Inner city England } \\
\cline { 2 - 3 } \cline { 5 - 6 } & Boys $(n=4845)$ & Girls $(n=4662)$ & & Boys $(n=2698)$ & Girls $(n=2703)$ \\
\hline Age (years) & $8.18(2.00)$ & $8.15(2.00)$ & & $8.02(2.00)$ & $8.13(2.00)$ \\
Height (SDS) & $0.11(0.98)$ & $0.07(1.00)$ & & $0.01(1.04)$ & $0.02(1.07)$ \\
Body mass index (SDS) & $0.05(1.07)$ & $0.02(1.07)$ & & $-0.18(1.25)$ & $-0.12(1.21)$ \\
Subcutaneous fatness (SDS) & $0.08(0.96)$ & $-0.004(0.94)$ & & $-0.03(1.05)$ & $-0.06(1.02)$ \\
Birth weight (g) & $3398.4(566.4)$ & $3272.9(548.7)$ & & $3208.6(597.7)$ & $3106.6(572.9)$ \\
\hline
\end{tabular}

Values are mean (SD).

SDS $=$ standard deviation score.

obtained from three samples. ${ }^{3}$ The English sample comprised 22 areas and the Scottish sample 14 areas, which were each selected by stratified random sampling of employment exchange areas using data on unemployment, early school leavers, and uptake of school meals in $1970 / 1$. The social class distribution of these two samples was similar to that of the general population and they will be referred to as the white representative sample. ${ }^{19}$ The third sample comprised children from 20 English inner city areas. Schools were selected according to characteristics of deprivation and proportion of ethnic groups. ${ }^{3}$ All children attending selected primary schools in each area in 1993/4 were included. A parent, usually the mother, was asked to complete a self-administered questionnaire concerning the child's asthma symptoms and sociodemographic information. The questionnaire was available in dual languages for the English inner city areas, English-Urdu, English-Gujarati, or English-Bengali. All children in the school whose parents did not refuse were weighed and measured. Height was measured on a specially designed stadiometer using the method described by Tanner et al. ${ }^{20}$ Children were weighed wearing only underpants using electronic digital scales. Triceps and subscapular skinfold thickness were measured as recommended by Tanner and Whitehouse, but for triceps skinfold thickness the mid point between the tip of the acromion and the olecranon was marked with the arm hanging straight instead of bent. ${ }^{21}$

Asthma as a dependent variable was defined as either at least one asthma attack in the previous year or a positive answer to the question "Does his or her chest ever sound wheezy or whistling?" The analysis was repeated using either persistent wheeze ("does he or she wheeze most days?") or at least one asthma attack in the last 12 months as the dependent variable. This approach was chosen because of cultural differences in the perception of asthma by ethnicity and possible differences in the association between obesity and asthma by severity of asthma. ${ }^{16} 18$

Table 3 Prevalence of asthma (wheeze or asthma attacks), asthma attacks and persistent wheeze in the 14908 children, stratified by sample, with odds ratios relative to the England and Scotland white representative sample

\begin{tabular}{|c|c|c|c|c|c|c|c|}
\hline & \multirow[b]{2}{*}{$n$} & \multicolumn{2}{|c|}{$\begin{array}{l}\text { White representative } \\
(n=9507)\end{array}$} & \multicolumn{2}{|c|}{$\begin{array}{l}\text { Inner city England } \\
(n=5401)\end{array}$} & \multirow[b]{2}{*}{$95 \% C I$} & \multirow[b]{2}{*}{ p value } \\
\hline & & $\%$ & OR & $\%$ & $O R$ & & \\
\hline Asthma & 2589 & 17.0 & 1.0 & 17.9 & 1.06 & 0.9 to 1.1 & 0.1 \\
\hline Asthma attacks & 1255 & 9.0 & 1.0 & 7.4 & 0.86 & 0.7 to 0.9 & 0.01 \\
\hline Persistent wheeze & 824 & 4.1 & 1.0 & 8.0 & 2.03 & 1.8 to 2.3 & $<0.0001$ \\
\hline
\end{tabular}

Two variables were used for assessing obesity - body mass index (BMI) and the sum of the triceps and subscapular skinfold thickness (sum of skinfolds). BMI was used as an independent continuous variable in standard deviation score (SDS) units calculated from the UK 1990 reference curves. ${ }^{22}$ The sum of skinfolds was expressed in SDS using the NSHG 1990 white representative sample for England as the reference group and used in the analysis as a continuous variable.

Categorical independent variables included in the analyses were sex, ethnic group, father's social class, family size, and study area. Ethnic group was determined by the field worker's subjective assessment in conjunction with the spoken language at home, and divided into the following groups: White, Afro-Caribbean, Urdu, Gujarati, Punjabi, "other South Asians", and "others". Father's social class was categorised as non-manual, skilled-manual, semi and unskilled-manual, one parent family (when the father was not a member of the household), and unknown. Family size was classified into groups of families with one child, two, three, four, or five or more children. Continuous variables included in the analyses were age, birth weight, and passive smoking as a result of either the mother or father smoking at home. Passive smoking was expressed as the number of cigarettes smoked at home per day and analysed as a continuous independent variable.

Children with no information on respiratory symptoms and those of unknown age and/or sex were omitted from the analyses. The relation between asthma prevalence and BMI or the sum of skinfolds was assessed using multiple logistic regression models with minimal adjustment for age and sex and with complete adjustment for the covariates described above. The dependent variable was asthma (asthma attacks or wheeze). A similar analysis was performed using asthma attacks or persistent wheeze as the dependent variable. The analyses were carried out separately for the representative sample and the inner city sample and presented as the odds ratio for outcome reference population at the 90th centile in comparison to the 10th centile. The 10th and 90th centiles of SDS $(-1.28$ and 1.28) were used. The interaction of sex and obesity on asthma was assessed in each analysis. A similar analysis was carried out stratified by sex. All covariates were defined a priori based on previous studies.

\section{Results}

A total of 18218 children were eligible to enter the study in the 1993 or 1994 surveys. Of those, $3310(18.2 \%)$ were excluded because they did not have information on respiratory illness. The demographic characteristics of the two samples are shown in table 1. Of the 9507 children in the representative sample, 5466 were from English areas and 4041 from Scottish areas. A higher percentage of children were from large families, belonged to semi or unskilled social classes, or were from one parent families in the inner city sample than in the representative sample. Children of the 
Table 4 Association between asthma (wheeze or asthma attacks), asthma attacks and persistent wheeze and fatness (BMI and sum of skinfolds) in the representative sample, odds ratios for the comparison of the 90th and the 10th centiles of SDS

\begin{tabular}{|c|c|c|c|c|c|c|c|c|c|}
\hline & \multicolumn{3}{|c|}{ Boys $(n=4845)$} & \multicolumn{3}{|c|}{ Girls $(n=4662)$} & \multicolumn{3}{|l|}{ Total } \\
\hline & $O R$ & $95 \% C I$ & $p$ value & $O R$ & $95 \% C I$ & p value & OR & $95 \% C I$ & p value \\
\hline \multicolumn{10}{|l|}{ Asthma } \\
\hline Unadjusted $\dagger$ & 1.25 & 1.05 to 1.47 & 0.01 & 1.36 & 1.11 to 1.67 & 0.003 & 1.29 & 1.13 to 1.47 & $<0.0001$ \\
\hline $\begin{array}{l}\text { Adjusted } \$ \\
\text { Skinfolds SDS }\end{array}$ & 1.26 & 1.05 to 1.52 & 0.01 & 1.31 & 1.05 to 1.65 & 0.01 & 1.28 & 1.11 to 1.48 & 0.001 \\
\hline Unadjusted & 1.14 & 0.95 to 1.38 & 0.1 & 1.16 & 0.92 to 1.46 & 0.2 & 1.15 & 0.99 to 1.33 & 0.05 \\
\hline $\begin{array}{l}\text { Adjusted } \\
\text { Asthma attacks } \\
\text { BMI SDS }\end{array}$ & 1.07 & 0.87 to 1.32 & 0.4 & 1.13 & 0.87 to 1.45 & 0.3 & 1.11 & 0.94 to 1.30 & 0.2 \\
\hline Unadjusted & 1.38 & 1.11 to 1.71 & 0.004 & 1.42 & 1.08 to 1.86 & 0.01 & 1.39 & 1.15 to 1.67 & $<0.0001$ \\
\hline $\begin{array}{l}\text { Adjusted } \\
\text { Skinfolds SDS }\end{array}$ & 1.37 & 1.08 to 1.74 & 0.01 & 1.45 & 1.07 to 1.96 & 0.01 & 1.39 & 1.18 to 1.65 & $<0.0001$ \\
\hline Unadjusted & 1.13 & 0.88 to 1.44 & 0.3 & 1.17 & 0.86 to 1.60 & 0.3 & 1.14 & 0.94 to 1.38 & 0.1 \\
\hline Adjusted & 1.05 & 0.80 to 1.37 & 0.7 & 1.21 & 0.86 to 1.70 & 0.2 & 1.11 & 0.90 to 1.37 & 0.3 \\
\hline $\begin{array}{l}\text { Persistent wheeze } \\
\text { BMI SDS }\end{array}$ & & & & & & & & & \\
\hline Unadjusted & 1.46 & 1.06 to 2.01 & 0.02 & 1.81 & 1.24 to 2.65 & 0.002 & 1.59 & 1.25 to 2.04 & $<0.0001$ \\
\hline $\begin{array}{l}\text { Adjusted } \\
\text { Skinfolds SDS }\end{array}$ & 1.29 & 0.89 to 1.86 & 0.16 & 2.07 & 1.33 to 3.24 & 0.001 & 1.57 & 1.18 to 2.07 & 0.002 \\
\hline Unadjusted & 1.29 & 0.91 to 1.85 & 0.1 & 1.51 & 0.98 to 2.31 & 0.05 & 1.38 & 1.05 to 1.81 & 0.02 \\
\hline Adjusted & 1.05 & 0.70 to 1.58 & 0.8 & 1.47 & 0.89 to 2.43 & 0.1 & 1.22 & 0.90 to 1.67 & 0.2 \\
\hline
\end{tabular}

$\mathrm{BMI}=$ body mass index; SDS = standard deviation score.

†Adjusted for age; adjusted for age and sex for the total sample.

¥Adjusted for age, birth weight, number of children, father’s social class, ethnicity, area and passive smoking.

inner city sample had lower mean height (SDS), mean BMI (SDS), and sum of skinfolds (SDS) than those in the representative sample (table 2).

The overall prevalence of asthma was $17.3 \%$ and was similar for the white representative and the inner city samples $(17.0 \%$ and $17.9 \%$, respectively). The prevalence of reported asthma attacks $(9.0 \%$ versus $7.4 \%)$ was significantly lower in the inner city sample (odds ratio (OR) $0.86,95 \%$ CI 0.7 to 0.9 ) than in the white representative sample. Persistent wheeze was considerably more prevalent $(4.1 \%$ versus $8.0 \%)$ in the inner city sample than in the representative sample (OR 2.03, 95\% CI 1.8 to 2.3; table 3).

Each of the three asthma outcomes was positively associated with BMI (SDS) after

Table 5 Association between asthma (wheeze or asthma attacks), asthma attacks and persistent wheeze and fatness (BMI and sum of skinfolds) in the inner city sample, odds ratios for the comparison of the 90th and the 10th centiles of SDS

\begin{tabular}{|c|c|c|c|c|c|c|}
\hline & \multicolumn{3}{|c|}{ Boys $(n=2698)$} & \multicolumn{3}{|c|}{ Girls $(n=2703)^{*}$} \\
\hline & $O R$ & $95 \% C I$ & $p$ value & $O R$ & $95 \% C I$ & $p$ value \\
\hline \multicolumn{7}{|l|}{ Asthma } \\
\hline Unadjusted $\dagger$ & 1.15 & 0.95 to 1.41 & 0.1 & 1.76 & 1.40 to 2.22 & $<0.0001$ \\
\hline $\begin{array}{l}\text { Adjusted } \neq \\
\text { Skinfolds SDS }\end{array}$ & 1.14 & 0.88 to 1.47 & 0.3 & 1.56 & 1.14 to 2.14 & 0.005 \\
\hline Unadjusted & 1.11 & 0.88 to 1.55 & 0.3 & 1.53 & 1.17 to 2.01 & 0.002 \\
\hline $\begin{array}{l}\text { Adjusted } \\
\text { Asthma attacks } \\
\text { BMI SDS }\end{array}$ & 1.20 & 0.77 to 1.60 & 0.2 & 1.46 & 1.02 to 2.09 & 0.03 \\
\hline $\begin{array}{l}\text { BMI SDS } \\
\text { Unadjusted }\end{array}$ & 1.17 & 0.89 to 1.55 & 0.2 & 2.19 & 1.54 to 3.09 & $<0.0001$ \\
\hline $\begin{array}{l}\text { Adjusted } \\
\text { Skinfolds SDS }\end{array}$ & 1.11 & 0.77 to 1.60 & 0.5 & 2.24 & 1.41 to 3.57 & 0.001 \\
\hline Unadjusted & 1.11 & 0.79 to 1.54 & 0.5 & 1.62 & 1.07 to 2.46 & 0.02 \\
\hline $\begin{array}{l}\text { Adjusted } \\
\text { Persistent wheeze } \\
\text { BMI SDS }\end{array}$ & 1.32 & 0.88 to 1.97 & 0.1 & 1.58 & 0.93 to 2.68 & 0.09 \\
\hline Unadjusted & 1.18 & 0.89 to 1.55 & 0.2 & 1.64 & 1.19 to 2.26 & 0.003 \\
\hline $\begin{array}{l}\text { Adjusted } \\
\text { Skinfolds SDS }\end{array}$ & 1.16 & 0.81 to 1.66 & 0.4 & 1.90 & 1.21 to 2.99 & 0.005 \\
\hline Unadjusted & 1.05 & 0.76 to 1.46 & 0.7 & 1.65 & 1.13 to 2.42 & 0.009 \\
\hline Adjusted & 1.21 & 0.81 to 1.81 & 0.3 & 2.11 & 1.26 to 3.54 & 0.005 \\
\hline
\end{tabular}

$\mathrm{BMI}=$ body mass index; SDS = standard deviation score.

*Total is not presented because of an interaction between sex and BMI on asthma

†Adjusted for age.

$\ddagger$ Adjusted for age, birth weight, number of children, father’s social class, ethnicity, area and passive smoking. adjustment for covariates in boys and girls in the representative sample (table 4 ). The interaction of sex and BMI on asthma was not statistically significant in any of the analyses of the representative sample. Except for one unadjusted analysis, none of the three asthma outcomes was significantly associated with sum of skinfolds in the representative sample.

The interaction between sex and BMI on any asthma outcome was statistically significant or of borderline significance and the interaction between sex and sum of skinfolds on persistent wheeze was just significant in the inner city area sample. BMI and sum of skinfolds were strongly and significantly associated with each of the asthma outcomes in girls but not in boys (table 5). There was no evidence of nonlinearity of the association between the asthma outcomes and BMI or sum of skinfolds divided in quintiles. In the inner city sample we examined the association between asthma and obesity individually in the main ethnic minorities and in a heterogeneous group of children who could not be classified as white, AfroCaribbean or from the Indian subcontinent and found a stronger association in AfroCaribbean and Punjabi girls than in the other ethnic groups.

\section{Discussion}

In this study BMI was associated with asthma in both sexes in the representative sample but was only significantly associated in girls in the inner city sample. Generally, skinfold thickness odds ratios were lower than BMI in the representative sample but were similar in girls in the inner city sample.

As in all observational studies, information bias may have been a problem in our study. Information bias may partially explain the results but not the clear message that fatness, or a proxy measure of fatness, is associated with asthma in children. Parents' perceptions of asthma in their child may vary according to ethnicity and social background. Persistent 
wheeze may be unrecognised as asthma in a large percentage of children from the ethnic minorities and inner city areas. ${ }^{23}$ In the NSHG we have not found an association between social class and obesity, but there are differences in fatness by ethnicity. ${ }^{24}$ Children from the Indian subcontinent tend to have lower weight-for-height and sum of skinfolds than children from other ethnic groups. Obesity and asthma may have been partly associated because of a varying perception of asthma and asthma symptoms between ethnic groups. We adjusted for ethnicity and study area in the analysis of the inner city sample. As the results are different for boys and girls in the inner city sample, information bias as an explanation of our results would also require that the perception of asthma between ethnic minorities varies according to the child's sex. Evidence for such a convoluted explanation is difficult to find.

Our study has several advantages in comparison with other studies. We used two indicators of fatness to assess the association between obesity and asthma, the sample size was large and the participation rate in the study was high, the anthropometric measurements were available for most eligible children and were taken by well trained personnel, and the assessments were carried out for all the major ethnic groups living in Britain. As our study is cross sectional, we cannot exclude reverse causality as an explanation. It has been reported that weight gain is associated with asthma and that finding suggests that obesity is a plausible aetiological component of asthma. ${ }^{8}$ However, it is also possible that asthma may be a risk factor for obesity as many parents believe that a child with asthma should not exercise. Thus, asthma may induce a sedentary lifestyle in asthmatic subjects which could result in an increase in fatness. Sedentary life may contribute to airway narrowing and asthma by reducing the extent to which bronchial muscle is stretched..$^{25}$

On the whole our results confirm the reports of an association between asthma and fatness in children. There were two unexpected results in our analysis: (1) BMI was more consistently associated with asthma than the sum of skinfolds and (2) the association of fatness and asthma restricted to girls was found only in the inner city sample.

$\mathrm{BMI}$ is a poorer indicator of fatness than sum of skinfolds in childhood as the percentage body fat of total weight in 4-10 year old children is on average only $15-17 \%$ in girls and $12-14 \%$ in boys. ${ }^{26}$ Further evidence that skinfold thickness is a better measure than BMI to assess fatness in the population has come from the demonstration that an increase in skinfold thickness over time preceded the increase in BMI in the USA and the UK. ${ }^{3}$ Thus, it would have been expected that the sum of skinfolds, a more direct measure of fatness than BMI, would have been more strongly associated with asthma than BMI. A possible explanation could be that the association of asthma and BMI was restricted to those with the highest BMI, say the upper quintile, but there was no significant non-linearity between BMI and asthma except in one of 12 analyses.
The usual assertion that skinfold thickness is notoriously difficult to measure accurately has not been confirmed by our experience. In the NSHG the variation of skinfold thickness measurement between field workers was small in comparison with between-child variation and the intraclass correlation for triceps skinfold was greater than 0.95 in our annual trials from 1992 to $1994 .{ }^{27}$ In comparison, skinfold measurements are less repeatable than measurements of weight and height. Another explanation could be that BMI may be more strongly associated with asthma than skinfold thickness because internal fatness may be more important than subcutaneous fat. However, this is an unlikely explanation because fatness is predominantly subcutaneous in children and adolescents, ${ }^{28}{ }^{29}$ and the waist to hip ratio and skinfold thickness in children, unlike in adults, are insensitive for assessing visceral fat. ${ }^{30}{ }^{31} \mathrm{~A}$ plausible explanation is that obese children are above average size and have advanced bone age. $^{32}$ Thus, children with increased fatness also have more muscle and bones and this would explain, together with measurement repeatability, why BMI is more strongly related to asthma than to sum of skinfolds in most analyses.

The interaction of sex and obesity in asthma observed in the inner city sample but not in the representative sample is consistent with previous reports in adults and adolescents. ${ }^{89}{ }^{11}$ It is the first report for such an interaction in prepubertal children. Fat as a percentage of total weight and skinfold thickness are both higher in girls than in boys before the age of five years. ${ }^{26}{ }^{33}$ This sex dimorphism does not appear to be related to ethnicity. ${ }^{34}$ Smaller airway size, sedentary life, dietary differences, and hormonal levels have been suggested as possible explanations for the association between obesity and asthma. ${ }^{9}$ We are not aware of studies showing sedentary or dietary differences in fat children between sexes but it is possible that girls may be less stimulated to perform vigorous exercise than boys. With regard to airway size, forced expiratory volume in one second $\left(\mathrm{FEV}_{1}\right)$ is slightly higher in boys than in girls aged 7-10 years and $\mathrm{FEV}_{1}$, but not forced expiratory flows $\left(\mathrm{FEF}_{25-75}\right.$ or $\left.\mathrm{FEF}_{75-85}\right)$, is lower in ethnic minorities than in whites. ${ }^{35}$ There is some evidence that obesity is associated with lower lung function. ${ }^{36}$ However, just before puberty $\mathrm{FEV}_{1}$ is slightly higher in girls than in boys and the lung function of ethnic minorities relative to whites is similarly less in both sexes. ${ }^{35}$

In relation to the hormonal explanation, oestrogen and progesterone have been implicated in asthma in adults and oestrogen levels tend to be higher in obese adults. However, the evidence is far from compelling. ${ }^{37}$ Differences in maturation patterns between ethnic groups may explain why sex dimorphism of the association between asthma and obesity is restricted to the inner city sample. Information on pubertal maturation in ethnic groups living in Britain is unavailable. As there are very low levels of gonadal steroids just before puberty, these are unlikely to explain the interaction of obesity and sex on asthma in one of the two 
samples in our study. ${ }^{38}$ Several associations of leptin make it an interesting link worth exploring. Leptin is highly related to obesity, negatively associated with testosterone, and positively associated with oestrogen. ${ }^{39} 40$ The serum leptin concentration is higher in girls than in boys during and after puberty, but there is a lack of consistency in relation to differences in leptin levels between the sexes before puberty. ${ }^{39}{ }^{40}$ Leptin is reported to increase Th1 and suppress Th2 cytokine production in mice. ${ }^{41}$ Thus, explanations for prepubertal sex dimorphism in the association of obesity and asthma is still unsatisfactory and reports confirming, or otherwise, this interaction in other communities are needed.

In conclusion, there is clear evidence that fatness is associated with asthma in children. BMI may be a better measure than skinfold thickness for assessing the association between asthma and obesity in children as obese children have proportionally more muscles and bones and calliper measurements are somewhat less repeatable than height and weight measurements. There were indications of sex differences between obesity and asthma mimicking the results obtained in adults, but a satisfactory explanation for such prepubertal sex dimorphism is unavailable.

The study was funded through the Department of Health and the Scottish Home and Health Department.

1 Burney PG, Chinn S, Rona RJ. Has the prevalence of asthma increased in children? Evidence from the national study of health and growth 1973-86. BM7 1990;300:130610 .

2 Fleming DM, Crombie DL. Prevalence of asthma and hay fever in England and Wales. BMF 1987;294:279-83.

3 Chinn S, Hughes JM, Rona RJ. Trends in growth and obesity in ethnic groups in Britain. Arch Dis Child 1998;78:5137 .

4 Hughes JM, Li L, Chinn S, et al. Trends in growth in England and Scotland, 1972 to 1994 . Arch Dis Child 1997;76 land and

5 Colhoum H, Prescott-Clarke P. Health survey for England 1994. Volume I: Findings. Joint Health Survey Unit, London: HMSO, 1996.

6 Seidell JC, de Groot LC, van Sonsbeek JL, et al. Associations of moderate and severe overweight with self-reported illness and medical care in Dutch adults. $\mathrm{Am}$ F Public Health 1986;76:264-9.

7 Negri E, Pagano R, Decarli A, et al. Body weight and the prevalence of chronic diseases. $\mathcal{F}$ Epidemiol Community Health 1988;42:24-9.

8 Camargo CA, Weiss ST, Zhang S, et al. Prospective study of body mass index, weight change, and risk of adult-onset asthma in women. Arch Intern Med 1999;159:2582-8.

9 Shaheen SO, Sterne JAC, Montgomery SM, et al. Birth weight, body mass index and asthma in young adults. Tho$\operatorname{rax} 1999 ; 54: 396-402$.

10 Chen Y, Dales R, Krewski D, et al. Increased effects of smoking and obesity on asthma among female Canadian: smoking and obesity on asthma among female Canadian: the national population hea

11 Huang SL, Shaio GM, Chou P. Association between body mass index and allergy in teenage girls in Taiwan. Clin Exp Allergy 1999;29:323-9.

12 Somerville SM, Rona RJ, Chinn S. Obesity and respiratory symptoms in primary school. Arch Dis Child 1984;59:9404.

13 Schwartz J, Gold D, Dockery DW, et al. Predictors of asthma and persisten wheeze in a national sample of children in the United States. Am Rev Respir Dis 1990;142: 555-62.
14 Kaplan TA, Montana E. Exercise-induced bronchospasm in non-asthmatic obese children. Clin Pediatr (Philadelphia) 1993;32:220-5.

15 Gennuso J, Epstein LH, Paluch RA, et al. The relationship between asthma and obesity in urban minority children and adolescents. Arch Pediatr Adolescent Med 1998;52: $1197-200$.

16 Luder E, Melnik T, DiMaio M. Association of being overweight with greater asthma symptoms in inner city black and Hispanic children. F Pediatr 1998;132:699-703.

17 Lusky A, Barell V, Lubin F, et al. Relationship between morbidity and extreme values of body mass index in adolescents. Int F Epidemiol 1996;25:829-34.

18 Duran-Tauleria E, Rona RJ, Chinn S, et al. Influence of ethnic group on asthma treatment in children in 1990-1: national cross sectional study. BMF 1996;313:148-52.

19 Rona RJ, Altman DG. National study of Health and Growth: Standards of attained height, weight and triceps skinfold in English children 5 to 11 years old. Ann Hum Biol 1977;4:501-23.

20 Tanner JM, Whitehouse R, Takaishi M. Standards from birth to maturity for height, weight, height velocity, and weight velocity: British children, 1965 Parts I and II. Arch Dis Child 1966;41:454-71, 613-35.

21 Tanner JM, Whitehouse RH. Standards for subcutaneous fat in British children. Percentiles for thickness of skinfolds over triceps and below scapula. BMF 1962;i:446-50.

22 Child Growth Foundation. BMI charts. UK cross-sectional reference data: 1990/91 (available from Child Growth Foundation, 2 Mayfield Avenue, London W4 1PW)

23 Duran-Tauleria E, Rona RJ. Geographical and socioeconomic variation in the prevalence of asthma symptoms in English and Scottish children. Thorax 1999;54:476-81.

24 Chinn S, Rona RJ, Gulliford M, et al. Weight-for-height in children aged 4 to 12 years. Eur 7 Clin Nutr 1992;46:489 500.

25 Platts-Mills TAE, Sporik RB, Chapman MD, et al. The role of domestic allergens. Ciba Foundation Symposium 1997; 206:173-89.

26 Davies PSW. Models of body composition. In: SJ Ulijaszek, FE Johnson, MA Preece, eds. The Cambridge encyclopedia of human growth and development. Cambridge: Cambridge University Press, 1998: 38

27 Rona RJ, Chinn S. The national study of health and growth. Oxford: Oxford University Press, 1999: 5-20.

28 Rice T, Despres JP, Daw EW. Familial resemblance for abdominal visceral fat: the HERITAGE family study. Int $\mathcal{F}$ Obes Relat Metab Disord 1997;21:1024-31.

29 Gower BA, Nagy TR, Goran MI. Visceral fat, insulin sensitivity, and lipids in prepubertal children. Diabetes 1999;48: $1515-21$.

30 Brambilla P, Manzoni P, Sironi S. Peripheral and abdominal obesity in childhood obesity. Int $\mathcal{F}$ Obes Relat Metab Disord 1994; 18:795-800.

31 Fox K, Peters D, Armstrong N, et al. Abdominal fat deposition in 11-year-old children. Int F Obes 1993;17:11-6.

32 Garn SM, Clark DC, Guire KE. Level of fatness and size attainment. Am F Phys Anthropol 1974;40:447-9.

33 Davies PSW, Preece MA. Body composition in children: methods of assessment. In: Tanner JM, Preece MA, eds. Physiology of human growth. Cambridge: Cambridge University Press, 1989: 95-107.

34 Eveleth PE, Tanner JM. Worldwide variation in human growth. 9th ed. Cambridge: Cambridge University Press, 1990

35 Chinn S, Rona RJ. Height and age adjustment for cross sectional studies of lung function in children aged 6-11 years. Thorax 1992;47:707-14.

36 Fung KP, Lau SP, Chow OKW, et al. Effects of overweight on lung function. Arch Dis Child 1990;65:512-5.

37 Forbes L. Do exogenous oestrogen and progesterone influence asthma? Thorax 1999;54:265-7.

38 Styne DM. The physiology of puberty. In: Brook CGD, ed. Clinical paediatric endocrinology. London: Blackwell Science, 1995: 234-52.

39 Ahmed ML, Ong KK, Morrell DJ, et al. Longitudinal study of leptin concentrations during puberty: sex differences and relationship to changes in body composition. f Clin Endocrinol Metab 1999;84:899-905.

40 Demerath EW, Towne B, Wisemandle W, et al. Serum leptin concentration, body composition, and gonadal hormones during puberty. Int $\mathcal{F}$ Obes Relat Metab Disord 1999;23:67885.

41 Lord GM, Matarese G, Howard JK, et al. Leptin modulates the T-cell immune response and reverses starvationinduced immunosuppression. Nature 1998;394:897-901. 